\title{
Social, Cultural and Economic Discrimination to Women Participation in African Politics: The Case of Nigeria
}

\author{
Mofoluwawo E.O (Ph.D) \\ Department Of Social Studies \\ Emmanuel Alayande College of Education, P.M.B 1010, Oyo, Oyo State \\ Email: emofoluwawo@yahoo.com
}

Doi:10.5296/ijld.v4i2.5427ＵRL: http://dx.doi.org/10.5296/ijld.v4i2.5427

\begin{abstract}
Women discrimination in politics is a phenomenon that excludes majority of women from politics. This practice is a waste of human resources. Nigerian women constitute about fifty percent of Nigeria's population and are known to play vital roles as child bearers, child rearers, house managers, producers of over $70 \%$ of the nation's food and community organizers among others. However, women's participatory level in government and decision making is below $50 \%$ currently. The causes of women discrimination in Nigerian politics are directly associated with gender complex because women are seen as inferior to men in our society and culture. Its roots are found in the past political, economic, social and cultural events which over the years have ensure the subjugation, oppression and domination of women by men. Women's discrimination in politics occurs everywhere be it in the developed or developing countries, thus perpetuating gender inequalities; this informed the declaration by the United Nations Goals Two, which is to "promote gender equality and empower women". This paper therefore examines the status of women in politics, problems women face in their quest to participate in politics, and possible measures to their political empowerment such as given political education to women and allowing women to participate at any level of political powers among others.
\end{abstract}

Keywords: Discrimination, Political Participation, and Women Participation.

\section{Introduction}

Discrimination against women is a global phenomenon as old as human history. Throughout the ages, there has always been bias and prejudice against women in all societies and in all epochs. Women's rights are the freedom and entitlement of women of human right without discrimination or violation. Women's rights are right inherent in nature and guaranteed by law. Therefore women discrimination and violence against women are contrary to fundamental human rights, equity, natural justice and good governance (Francis, 2012). The slogan "Women's Right are Human Rights adopted at the world conference on Human Rights in Vienna in 1993 and the Declaration on the Elimination of violence against Women by the General Assembly the same year further demonstrates the increasing awareness and the attention being paid to the respect of the right of women. Women's right around the world is an important indicator to understand global well-being. However despite many successes in empowering women, numerous issues still exist in all areas of life ranging from cultural, political to economic. For instance, women often work more than men, yet are paid less. Discrimination affects women and girls throughout their life time and they are often the ones that suffer the most poverty (Francis, 2012) 
Political participation is the voluntary activity by which members of a society share in the selection of rulers directly or indirectly and in the formation of public policy. Women participation in politics seems to be one of the contending issues facing world democracies in Africa and Nigeria in particular. Hague and Hagrop, (2001) opined that in 2000, women made up just 14 per cent of the world's legislators. This figure doubled the figure of twenty five years earlier but can still be a large under-representation. Suffice it to say that women representation in legislature around the world is 15 percent. (Lorngurum, 2010)

In Nigeria, about half of the population is made up of the female gender having distinguished themselves in their chosen careers. According to Ojo,(2011) women in politics form bulk of the electorate and campaign mobilizers. Despite the significant role of women in Nigeria before and after independence, the development correspondence, economic, social and political power is nothing to write home with (Anifowose, 2004). In the words of Irabo,(2011) however, the marginalization of Nigerian women in politics and decision making is also as old as old as the Nigerian society. It even predates the advent of colonialism in Southern and Northern Nigeria. The participation of women and men in formal and informal decision making structures varies greatly between countries but is generally in favor of men. Institutional as well as cultural, economic and societal factors limit women's opportunities and abilities participate in politics and decision making.

Women participation in politics in Nigeria seems to be one of the contending issues facing democracies in the world and Nigeria in particular. To corroborate the above reasons, Haque and Harrop (2001) submitted that as a group, women's still possess fewer political resources among men. The reasons being that women's interest in politics is sometimes limited by the biological mode of patriarchal and economic mode of capitalism, marriage to certain section of the country where women are not allowed to participate in politics, cultural where some cultures prohibit women involvement in politics, religious factors where women have some reservation, child bearing and homemaking responsibilities. Further, some women lack confidence needed to throw themselves into the hurly-burly of formal male led politics while many still face the hurdle of discrimination from sexist male political (Gaeren and Burya, 2011).

The return of democracy has even added another significant challenge to woman participation in political process of Nigeria. A vivid example was the general election of 2011 that was taken over by men with their male dominated model of politics (Daily Sun, 2011). It was also argued that women participation in political structure and processes where decisions regarding the use of societal resources are made still remain insignificant. Lorngurum (2010) reiterated further that so many efforts have been made to bridge the gender gap in the political arena. The efforts were reinforced by the convention on Elimination of All Forms of Discrimination Against Women(CEDAW)and the Beijing platform of action, there were only twelve countries where women hold thirty three(33)percent or more sits in the parliaments(UNDP, Reports, 2005). It is rather unfortunate that Nigeria is no one of the twelve countries. Women's low political participation is therefore often used as an indicator of gender inequality. Specifically, the 'proportion of seats held by women in national parliament' was chosen as one of the three indicators to measure progress on Millennium Development Goal 3(MDG3) on gender equality and women's empowerment.

In Nigeria, women are underrepresented not only in the political sphere but also in decision making within the private sector, at the village level and in the civil society. At the local level, men usually dominate positions of power, including religious and traditional leaders, local politicians and village elders. Ihonvbere, (2000) reported that this anomalies have impacted negatively on the development of women rights, despite the many international norms and institutions designed to advance the cause of women. There is the need to look into 
measures to increase women participation in politics for national development. It is against this background that this paper is out to provide answers to the following question:

i. What is the level of women participation in the Nigerian political sphere?

ii. What are the challenges to women participation in Nigerian politics?

iii. What are the proposing measures to increase women participation?

\section{CONCEPTUAL CLARIFICATION}

\section{Chapman Theoretical Model}

According to Chapman(1993)theoretical model, men are the major determinants of political actions and inactions and they are generally concerned with the perpetuation of the status quo. He goes further to observe that when women compete with men for access to political elites, they do so on the term already established by men for competition among themselves. The success of women in politics like that of any male out-group, cannot be achieved within such system without displacing or replacing existing elite and without some changes in values, and it cannot occur independently of fundamental changes in socio-economic as well as political relations. This is to say that without clear understanding of the way men regulate their own access to political elites, the conditions which govern that of women will remain obscure. The implication of this is that dictate the tempo of political activities in African society and Nigeria in particular.

\section{POLITICAL PARTICIPATION}

Political participation is the activities by which individuals formally intended to influence either who governs or the decisions taken by governments (Hague and Harrop 2001). Political participation means those activities by which members of a society share in the selection of rulers directly and in the formation of public policy.

\section{WOMEN AND POLITICAL PARTICIPATION IN NIGERIAN POLITICS}

Women involvement and representation in Nigerian politics at both local and federal levels was very low. Women participation in decision making at all level has been very low, warranting the conclusion that women are at the periphery of the Nigeria politics, despite the fact that they have been constituting a larger proportion of active voters. For instance, out of the 47 million Nigerians who registered as eligible voters in the 1999 election, 27 million were women, representing 57.4 percent of registered voters. The registration of Nigerian women has always at par with that of men in the entire census so far concluded in the country; yet the percentage of women in elective position when compare with men, is very abysmal (Nda, 2003). It should be noted however that women have been involved though in a passive way long before the colonial masters. For instance, women like Moremi of Ile-Ife, legendary Queen Amina of Zazzau in Zaria who was reported to have ruled over an empire and Queen Idia of Benin, Madam Tinubu of Lagos and so on have sacrificed themselves in the service of their varied communities. With much enlightenment, women mounted pressure on the president Obasanjo's administration to increase the percentage of women representation to $30 \%$ percent into elective political offices (Wrapa Newsletter 2002). Fayemi (2011) even opined that despite the fact that women belong to several political parties in Nigeria, they nearly contest for leadership positions within the parties or in the larger society. The reason may be because men in politics prefer to hold political meetings at night and women were hardly involved where party programmes, strategies and tactics are drawn. Coupled with the above is the fact that religion, tradition, socio-economic status as well as societal problems also militates against women participation in politics.

Suffice it to say that some women in Nigerian politics could not be forgotten because many of them were elected into various positions both within and outside Nigeria. These include 
Olusola Obada and Latifa Okunnu who were the first female deputy governors of Osun and Lagos state respectively. Khairat Gwadabe, Stella Omu, Florence Ita-Giwa and Iyabo Obasanjo Bello were senators while Magret Isheen has been speaker for Benue State House of Assembly, Abike Dabiri is an honourable member of house of representatives. Outside Nigeria, Ellen Johnson Sirleaf was the elected female president of Liberia(2006-2011) and Nichelle Rachets who became the first elected president of Chile in 2006.

Many countries have complied with the United Nations Treaty Convention on the Elimination of all forms of Discrimination Against Women to some extent. But the situation in Nigeria seems that there is a written policy to exclude women from equal representation in top political positions. The CEDAW report presents comprehensive statistics of women participation and representation in the last four general elections as shown in the table below.

TRENDS OF WOMEN PARTICIPATION IN POLITICS IN NIGERIA FROM 1999 TO 2011

\begin{tabular}{|c|c|c|c|c|c|c|c|c|c|c|}
\hline & & \multicolumn{3}{|c|}{1999} & \multicolumn{2}{|l|}{2003} & \multicolumn{2}{|l|}{2007} & \multicolumn{2}{|l|}{2011} \\
\hline$\tilde{z}$ & 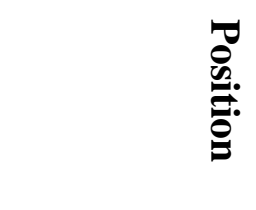 & 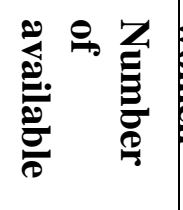 & 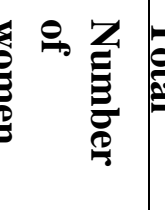 & $\begin{array}{l}0_{0}^{1} \\
0 \\
0 \\
0\end{array}$ & 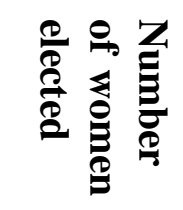 & 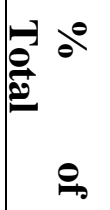 & 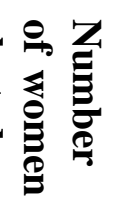 & 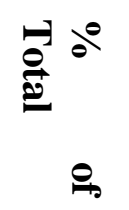 & 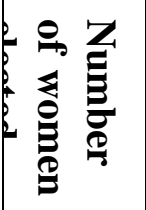 & $\underbrace{-1}_{0} a^{9}$ \\
\hline 1 & Presidency & 1 & 0 & 0 & 0 & 0 & 0 & 0 & 0 & 0 \\
\hline 2 & Senate & 109 & 3 & $\begin{array}{l}2.7 \\
5\end{array}$ & 4 & 3.7 & 9 & 8.38 & 7 & 6.4 \\
\hline 3 & $\begin{array}{l}\text { House of } \\
\text { Representativ } \\
\text { es }\end{array}$ & 360 & 12 & $\begin{array}{l}3.3 \\
3\end{array}$ & 21 & 5.83 & 23 & 6.38 & 19 & 5.27 \\
\hline 4 & Governorship & 36 & 0 & 0 & 0 & 0 & 0 & 0 & 0 & 0 \\
\hline 5 & $\begin{array}{l}\text { Deputy } \\
\text { Governorship }\end{array}$ & 36 & 0 & 0 & 2 & 5.5 & 6 & 16.30 & 1 & 2.3 \\
\hline 6 & $\begin{array}{l}\text { State Houses } \\
\text { of Assembly }\end{array}$ & 990 & 12 & $\begin{array}{l}1.2 \\
1\end{array}$ & 38 & 3.84 & 53 & 5.25 & N/A & N/A \\
\hline
\end{tabular}

N/A = Not Available

Source: Partly adapted from www.un.org/womenwatch/2011election and www.inecnigeria.org/2011election

The table revealed percentage of women participation in politics. The year 1999 revealed $2 \% 2003$ general election revealed 4\%, 2007 revealed 8\% and 2011 revealed 6\% which is a reduction compare to 2007 .

\section{FACTORS MILITATING AGAINST WOMEN PARTICIPATION IN NIGERIAN POLITICS}

Different factors are attributed to little participation of women in Nigerian politics. These include socio-cultural factor, fear of domination and lack of solidarity among women, lack of fund or economic factor, mental and family commitment, indigene-ship factor, political insecurity, harassment and representation, step down factor and representation.

\section{Socio-Cultural Factor}

In the cultural and traditional environment in Nigeria, as male child grow up, he finds out that his sex confers something extra on him. Women are deprived of basic rights using culture and tradition to justify the abuse in the following practices: husbands are the heads of families and their decisions are final. Women must respect and obey their husbands at all times. Also most women spend their lives with marriage. 
According to Rai (2000) women find it hard to participate in politics due to limited time available to them because of their duties in the productive and reproduction spheres. Women as mothers and wives are confronted with competing domestic work and responsibilities. Hence, they are left with little time to participate in politics

\section{Economic Factor}

Not many women are financially buoyant to participate in Nigerian politics. Politics in Nigeria is becoming increasingly commercialized. More money is needed to participate in the politics. Women participation in the politics of Nigeria was therefore limited because many women did not have access to ownership of productive resources. Also the idea of vote buying which is peculiar to Nigerian politics may not favour the women. Vote buying has implications for female candidates as many of them are not economically buoyant like their male competitors and may not be able to influence their voters with money as recorded in 2011 general election (Ojo, 2011). Added to that was the fact that about $70 \%$ of the 1.3 billion women are living in on less than a dollar per day (World Bank 2001). This indicated that gender inequalities in developing countries inhibit economic growth; and there is a correlation between gender discrimination and greater poverty, slower economic growth, weaker government and lower standard of living of the people (World Bank, 2001).

\section{Fear of Marginalization by Men and Lack of Solidarity among Women}

This is another factor that is militating against women participation in Nigeria. There was massive displacement of the female aspirants from Peoples Democratic Party (PDP) in the primaries of the parties. This singular act frustrated women to participate in politics. It should be stressed that not much was done to improve the lot of the few women in the top positions by their female counterparts. The reason may be because they have been influenced by the men who appointed them.

\section{Political Insecurity, Harassment, Violence, Thuggery, Uncertainties and Intimidation}

These are also strong factors militating against the participation of women in Nigerian politics. This is because of lack of adherence to rules of democracy by large number of actors. This is the more reason why politics is considered as a dirty game and exclusive right of thugs and hooligans in Nigeria. No wonder, Nigeria politics is characterized by assault, assassination, harassment, acrimony, intimidation, maiming and killing (Obasanjo, 2002, Akunyili, 2010). The country's storm-like political atmosphere therefore favours men to the detriment of Nigerian women. Women by nature are too weak to face the storm of politics. Politics of Nigeria was even regarded for the tough and cannot be contemplated by the weakling. Women by nature like to preserve their dignity anywhere. The fear of being attacked is always in the heart of women. Political sphere is often viewed as area where men have superior knowledge.

\section{Indigene-Ship Factor and Representation}

Nigeria's political atmosphere poses another challenge called indigene-ship factor or 'son of the soil factor'. An individual is firstly expected to be recognized as a citizen before ethnic group but in Nigeria, the ethnic group comes first in most cases in Nigeria and this has a huge effect on women's level of participation. In the Nigerian tradition, the society bestows respects on women based on marriage and it is something regarded as important for every woman who automatically changes her state of origin and become a member of her husband's ethnic group. Ironically, in political environment the woman is not fully regarded as a full member of that community rather she is seen as a foreigner and a member by marriage alone and therefore should not be given the right that should be for the 'son of the soil'. The case is 
even worse for a foreign woman married to a Nigerian because she may never be appointed into any noteworthy political office because she can never be considered as true 'indigene' of any state (CEDAW,2008). The parties often use it to disqualify women or discourage them from being flag bearers for the party during elections since they believe the political environment is hostile to such candidate that fit the profile.

\section{Step Down Factor and Representation}

In most cases in Nigeria's political sphere, candidates who are eligible to contest are asked to step down for a more 'suitable' male candidate despite the outcome of pre-election to allow the person a better chance of winning the main election. Hon.Adefulire (Deputy Governor of Lagos State) of the ACN party confirms that this is a major limitation to women involvement in politics (Olamitoke, 2011).

\section{APPROACHES TO INCREASE WOMEN PARTICIPATION IN NIGERIAN POLITICS}

The following are suggested approches to increase active women participation in Nigerian politics:

$>$ Our Society's quest for social stratification or prestige on the basis of gender should give way to equal opportunities for all citizens. The Nigerian constitutional provision of equity for all citizens should be enforced to the letter.

$>$ Political education on women participation. Female aspirants should be equipped with relevant skills that match the position to be desired. The result of this would enable the aspirant to address gap to reposition them for the necessity of electoral campaigns and elective office.

$>$ Also, women non-governmental organisation should make sure that legislative and administrative reforms to give women full and equal access to economic resources are undertaken in Nigeria. Women should also be given right to ownership and inheritance of land as required in the Beijing Platform For Action (BADBAB, 2011). Women activists in Nigeria should also create awareness on provision relating to $35 \%$ affirmative action and demand for electoral accountability from political parties.

\section{Conclusion}

Women discrimination is an anathema to human existence, healthy relationship and development. Ignorance contributes to women discrimination and violation of rights. At creation almighty God saw the need for women to compliment men in his stride for survival and development. There is therefore no doubt that Nigerian women have potential to contribute to Nigeria's transformation. Women should be given equity in harnessing available resources. Exclusion of women in Nigerian politics and our national life has made us lose a lot of human resources that if well-garnered could help situate Nigeria and Africa properly and beneficially in the world global systems. Since culture is not static but dynamic, the dynamism of culture should prompt Africa and Nigeria to march forward and liberate the productive forces of our women for self-actualization, political and national development. This will enable Nigerian women never to be only westernised but will take their rightful position in the scheme of things globally.

\section{REFERENCES}

Akunyili, D. (2010). An interview granted in Sunday Tribune, May 28, 2010

Anifowose, R. (2004). Women Political Participation in Niger: Problems and Prospects in Akinboye S.O (ed) 2004. Paradox of Gender Equity in Nigerian Politics, Lagos Concepts Publication Limited 
Bari, F. (2005). Women's Political Participation: Issues and Challenges. EGM/WPDEE2005| EP 12.

Chapman, F.(1993). Politics, Feminism, and the Reformation of Gender, Routledge, New York.

Fayemi, J.A (2011) Gender and Politics in Nigeria: Which Way Forward. Ijebu Ode: Tunigraphic Prints

Francis, O.A. (2012) Reducing Gender Discrimination and Violence Against Women Through Library and Information Services Retrieved from http://uniHib.unl.edu/LPP/ on 26/7/2013

Gbaeren, F.I and Burya, A.M. (2011) Citizenship and Women Participation in Politics: Problems and Prospects for the Actualisation of Vision 202020 in Nigeria. Journal of Women in Colleges of Education (JOWICE) 15 (1), 2011.

Hague, R and Harrop, M. (2001) Comparative Government and Politics, an Introduction. New York: Palgrave Publishers Ltd

Lorngurum, H.N. (2010). Women Participation in Society and Decision-Making in Nigeria, Katsina-Ala Journal of Women in Colleges of Education 1 (1) pp7-15

Nda, L. H. (2003)."Women in the Power Equation of Nigerian Politics" in Mike Kwanashie, ed, Op.Cit

Obasanjo, O (2002) $42^{\text {nd }}$ Nigeria Independence Anniversary National Broadcast. Tell Magazine, No.41 October 14, 2002.

Olamitoke, T. (2011). Democracy in Nigeria: How Have the Women Fared? Retrieved from Tribune. Com.ng.Isat/index.php/women affairs.

Ojo, J. (2011). Nigeria Women and National Development. The Punch, June 14, 2011 pg16

Rai, M. Shirin (2000). International Perspective on Gender and Governance, Great Britain Macmillian Press.

Thompson, E. (2006). "Women Participation in Nigeria". A paper presented at the International Federation of Women Lawyers(FIDA) Rivers State Zone.

Wrapa Newsletter, (2002). “Women's Rights and Due Process: Benefits and Gains vol 5.(1) October-December. 